\title{
HUBUNGAN RESPONSE TIME PERAWAT DENGAN TINGKAT KEBERHASILAN PENANGANAN PASIEN EMERGENCY
}

\author{
Bintang Bisri Musthofa ${ }^{1}$, Ni Luh Widani ${ }^{2}$, Budi Sulistyowati ${ }^{3}$ \\ ${ }^{1,2}$ Sekolah Tinggi Ilmu Kesehatan Sint Carolus Jakarta \\ ${ }^{3}$ Radjak Hospital \\ Email: widani24@gmail.com
}

\begin{abstract}
Response time is the speed in handling patients, calculated from the time the patient arrived until get the treatment. One of the factors that influence the success rate of patient handling is response time. The study aims to determine the relationship of nurse responsiveness with the success rate of emergency patient management in Emergency Unit Hospital X. This study uses a quantitative method, correlative descriptive design. Data collection through observation from the time the patient arrived until the treatment decision (going to), on December 13 2019-3 January 2020. A sample of 321 respondents, taken by purposive sampling, analysis used the Kendalls tau B Test. The results of univariate analysis showed that the majority of patients came to ED is an adult age 57.9\%, female 54.5\%, emergency level of the patient is $2^{\text {nd }}$ Priority $94.7 \%$, nurse's response time is in accordance 99.4\%, successful patient handling rates $99.4 \%$. The results of Kendalls tau $b$ Analysis, get data by statistic there was no significant relationship between nurses response time with the success rate of handling emergency patients with p-value 0,314 (>0,05). Conclusion: the success rate of handling emergency patients is not only affected by nurses reponse time but there are the complexity of medical diagnosis of patients, and pre hospital handling. Suggestion for the next researcher can inspect the complexity of patient medical diagnosis and their response time then relate it with the success rate of emergenncy patient handling.
\end{abstract}

Keywords/Kata Kunci : Emergency, Emergency Department, Response Time, Success Rate

\section{PENDAHULUAN}

Rumah sakit merupakan institusi pelayanan kesehatan yang melaksanakan pelayanan kesehatan perorangan secara paripurna yang menyediakan pelayanan rawat inap, rawat jalan, dan gawat darurat (Keputusan Menteri Kesehatan, 2009). Salah satu bagian dari Rumah Sakit yang memberikan pelayanan adalah Instalasi Gawat Darurat, yang merupakan wajah dan pintu utama jalan masuknya pasien gawat darurat. IGD adalah suatu instalasi di rumah sakit yang dirancang secara khusus untuk menangani trauma atau penyakit yang akut (Pusponegoro \& Sujudi, 2016).

Triage adalah suatu cara memilah dan menentukan korban berdasarkan kebutuhan terapi dan sumber daya yang tersedia. Prinsip penatalaksaan primer yang diprioritaskan pada ABCDE (Airway, Breathing dan Circulation, Disability dan Exposure) yang kemudian dilanjutkan dengan resusitasi (Sartono, Masudik, \&Suhaeni, 2016).

Response time penanganan pasien perlu diperhitungkan agar terselenggaranya pelayanan yang cepat dan yang terpenting

DOI : https://doi.org/10.51544/imn.v4i1.1265

(C) 2021 Jurnal Mutiara Ners. This is an open accessarticleunder the CC BY-SA license Website : http://e-journal.sari-mutiara.ac.id/index.php/NERS/index 
adalah mampu menyelamatkan pasien gawat darurat (Keputusan Menteri Kesehatan, 2008). Beberapa kasus, Ischemic melebihi34 menit pada suhu normal akan menyebabkan serebri rusak menetap.Statistik membuktikan bahwa hampir 90\% korban meninggal ataupun cacat disebabkan karena korban terlalu lama dibiarkan atauwaktu ditemukan telah melewati "the goldentime period" dan ketidaktepatan serta akurasi penolong pertama saat pertama kali korban ditemukan. (Sartono et al, 2016)

Standar indikator pelayanan minimal suatu rumah sakit menentukan jumlah kematian pasien di IGD<8jam tidak boleh lebih dari 2 perseribu dalam kurun waktu 1 tahun, yang mana menjadi tolak ukur keberhasilan response time pelayanan instalasi gawat darurat dalam melakukan penanganan pasien (Keputusan Menteri Kesehatan, 2008).

Di IGD RS X yang mana adalah rumah sakit tipe $\mathrm{C}$ di daerah Jakarta Barat, menggunakan sistem triage PACS (Patient Acuity Category Scale) dengan modifikasi. Response time untuk pasien prioritas 1 adalah $<5$ menit. Dalam pelaksanaannya, terdapat beberapa kendala dengan adanya triage ini seperti ketidaktersediaannya perawat khusus triage. Semua tenaga medis (perawat maupun dokter) akan melakukan triage jika petugas tersebut menerima pasienyang baru datang.

Alur penanganan pasien yang sementara ini berlaku di RS X adalah pasien dilakukan triage oleh perawat dan dokter di IGD, kemudian untuk pemberian terapi keluarga harus mengambil obat-obatan untuk pasien di farmasi yang terletak di lantai dua Rumah Sakit. Jarak dan waktu yang ada menjadikan berkurangnya efektivitas response time terhadap pasien.
Hal ini menyebabkan triage menjadi kurang efektif, menimbang pentingnya fungsi triage dan akan mempengaruhi tahap penanganan pasien selanjutnya.

IGD RS X Memiliki kunjungan pasien pada Januari tahun 2019 sebanyak 1182 jiwa. tingkat keberhasilan penanganan pasien adalah 1,75/1000. Angka ini mendekati standar yang dimiliki oleh kemenkes yakni 2/1000. Dalam 3 bulan berturut-turut, hampir di setiap bulannya ditemukan adanya kasus DOE. Dalam kondisi ini peneliti tertarik untuk melakukan penelitian tentang Hubungan response time perawat dengan tingkat keberhasilan penanganan pasien emergency di IGD RS X.

\section{METODE PENELITIAN}

Penelitian ini merupakan penelitian kuantitatif dengan desain penelitian deskripsi korelasi. Penelitian dilakukan di RS Cinta Kasih Tzu Chi Cengkareng pada 13 December 2019 s.d. 3 Januari 2020. Instrumen dalam penelitian ini menggunakan lembar observasi. Populasi dalam penelitian ini adalah keseluruhan pasien IGD RS X sejumlah 632 responden. Sampel dalam penelitian ini mengunakan purposive sampling dengan kriteria inklusi pasien prioritas I dan II sebanyak 321 responden.

Analisis data univariat digunakan untuk mengetahui gambaran karakteristik responden serta distribusi frekuensi. Pengolahan data penelitian menggunakan pendekatan statistik. Pengujian hipotesis dalam penelitian ini menggunakan uji analisis korelasi kendalls tau $b$ menggunakan aplikasi komputer. 


\section{HASIL}

Karakteristik responden yang ditampilkan dalam penelitian dalam penelitian inimeliputi usia, jenis kelamin, klasifikasi tingkat kegawatan, response time perawat, dan tingkat keberhasilan penanganan pasien emergency

Tabel 1. Distribusi Frekuensi Usia Pasien

\begin{tabular}{ccc}
\hline Usia & n & \% \\
\hline$\leq 1$ Tahun (Bayi) & 39 & 12,1 \\
2-17 Tahun (Anak) & 68 & 21,2 \\
18-64 (Dewasa) & 186 & 57,9 \\
$>$ 64 Menit (Lansia) & 28 & 8,7 \\
\hline Total & $\mathbf{3 2 1}$ & $\mathbf{1 0 0}$ \\
\hline
\end{tabular}

Pada tabel 1 didapatkan mayoritas pasien yang datang ke IGD RS X adalah pasien dengan kategori dewasa (18-64) tahun, yaitu sebanyak $186(57,9 \%)$ responden.

Tabel 2. Distribusi Frekuensi Jenis Kelamin Pasien

\begin{tabular}{lccc}
\hline \multicolumn{2}{c}{ Jenis Kelamin } & n & \% \\
\hline Laki-laki & & 146 & 45,5 \\
Perempuan & & 175 & 54,5 \\
\hline \multicolumn{2}{c}{ Total } & $\mathbf{3 2 1}$ & $\mathbf{1 0 0}$ \\
\hline
\end{tabular}

Dari data responden berdasarkan jenis kelamin yang termaktub dalam tabel 2, mayoritas pasien yang datang ke IGD untuk mendapatkan perawatan adalah pasien dengan jenis kelamin perempuan sebanyak $175(54,5 \%)$ pasien.

Tabel 3. Distribusi Frekuensi Tingkat Kegawatan pasien

\begin{tabular}{lcc}
\hline \multicolumn{1}{c}{ Triage } & n & \% \\
\hline $\begin{array}{l}\text { PAC 1 } \\
\text { Patient Acuity Category Scale 1) }\end{array}$ & 17 & 5,3 \\
$\begin{array}{l}\text { PAC 2 } \\
\text { Patient Acuity Category Scale 2) }\end{array}$ & 304 & 94,7 \\
\hline \multicolumn{1}{c}{ Total } & $\mathbf{3 2 1}$ & $\mathbf{1 0 0}$ \\
\hline
\end{tabular}

Berdasarkan tabel 3, didapatkan data mayoritas pasien yang datang ke IGD dengan tingkat kegawatan PAC 2 sebanyak 304 (94,7\%) pasien.

DOI : https://doi.org/10.51544/imn.v4i1.1265

(C) 2021 Jurnal Mutiara Ners. This is an open accessarticleunder the CC BY-SA license

Website : http://e-journal.sari-mutiara.ac.id/index.php/NERS/index 
Tabel 4. Distribusi Frekuensi Response Time Perawat

\begin{tabular}{lccccc}
\hline \multirow{2}{*}{ Response Time } & \multicolumn{2}{c}{$\begin{array}{c}\text { Tindakan } \\
\text { Mandiri }\end{array}$} & & \multicolumn{2}{c}{$\begin{array}{c}\text { Tindakan } \\
\text { Kolaboratif }\end{array}$} \\
\cline { 2 - 3 } & $\mathbf{n}$ & $\boldsymbol{\%}$ & & $\mathbf{n}$ & $\boldsymbol{\%}$ \\
\hline Sesuai & 321 & 100 & 319 & 99,4 \\
Tidak Sesuai & 0 & 0 & 2 & 0,6 \\
\hline \multicolumn{1}{c}{ Total } & $\mathbf{3 2 1}$ & $\mathbf{1 0 0}$ & $\mathbf{3 2 1}$ & $\mathbf{1 0 0}$ \\
\hline
\end{tabular}

Berdasarkan tabel 4 didapatkan data mayoritas response time perawat dalam tindakan mandiri adalah sesuai dengan kriteria kegawatannya, sedangkan response time perawat dalam tindakan kolaboratif yang sesuai dengan kriteria kegawatannya sebanyak $319(99,4 \%)$ pasien.

Tabel 5. Distribusi Frekuensi Tingkat Keberhasilan Penanganan Pasien Emergency

\begin{tabular}{ccc}
\hline $\begin{array}{c}\text { Tingkat Keberhasilan } \\
\text { Penanganan Pasien }\end{array}$ & n & \% \\
\hline Berhasil & 319 & 99,4 \\
Tidak Berhasil & 2 & 0,6 \\
\hline \multicolumn{1}{c}{ Total } & $\mathbf{3 2 1}$ & $\mathbf{1 0 0}$ \\
\hline
\end{tabular}

Berdasarkan tabel 5 didapatkan data mayoritas tingkat keberhasilan dalam penanganan pasien emergency di IGD adalah berhasil sebanyak $319(99,4 \%)$ pasien.

Tabel 6. Hubungan Response Time Perawat dengan Tingkat Keberhasilan Penanganan Pasien Emergency

\begin{tabular}{cccc}
\hline \multirow{2}{*}{ Response Time Perawat } & \multicolumn{2}{c}{ Keberhasilan Penanganan } & \\
\cline { 2 - 3 } & Berhasil & $\begin{array}{r}\text { Tidak } \\
\text { berhasil }\end{array}$ & p-value \\
\hline Sesuai & 317 & 2 & \multirow{2}{*}{$\mathbf{0 , 3 1 4}$} \\
\hline Tidak Sesuai & 2 & 0 & \\
\hline Total & $\mathbf{3 1 9}$ & $\mathbf{2}$ & \\
\hline
\end{tabular}

Berdasarkan tabel 5.6 didapatkan data mayoritas response time yang sesuai memiliki tingkat keberhasilan sebanyak 317 pasien. Hasil uji kendall's tau b didapatkan $p$-value $=0,314>0,05$ yang artinya tidak ada hubungan yang bermakna antara response time perawat dengan tingkat keberhasilan penanganan pasien emergency. 


\section{PEMBAHASAN}

Pada tabel 1 didapatkan mayoritas pasien yang datang ke IGD adalah pasien dengan kategori dewasa (18-64) tahun, yaitu sebanyak $186(57,9 \%)$ responden. Hasil ini sesuai dengan penelitian yang dilakukan Fadhilah (2015) bahwa mayoritas pasien yang datang dengan trauma adalah pasien kategori dewasa. Dalam pengamatan saat dilakukan observasi, pasien dewasa yang datang ke lebih sering ditemui dengan kondisi trauma, dan dengan penyakit kronik. Furwanti (2014) mengemukakan bahwa kematangan dapat diamati secara objektif dari usia, yang menunjukkan pengalaman, wawasan, keterampilan dan kemandirian. Oleh karena itu kondisi dewasa lebih memiliki pengalaman yang lebih mendalam menyikapi kondisi kesehatannya

Dari data responden berdasarkan jenis kelamin yang termaktub dalam tabel 2, mayoritas pasien yang datang ke IGD untuk mendapatkan perawatan adalah pasien dengan jenis kelamin perempuan sebanyak $175(54,5 \%)$ pasien. Hasil ini sesuai dengan penelitian yang dilakukan oleh Kundiman (2019) dari total sampel 105 responden pasien yang datang ke IGD, sejumlah 56 $(53,3 \%)$ responden adalah pasien berjenis kelamin perempuan. Kundiman juga menyatakan dalam penelitiannya bahwa perempuan lebih mencemaskan situasi dan kondisinya dibanding laki-laki.

Dalam pengamatan peneliti, pasien berjenis kelamin perempuan lebih banyak datang dengan masalah internist. Dengan demikian menurut analisis peneliti bahwa perempuan lebih mencemaskan kondisinya yang menyebabkan kondisinya lebih rentan terkena sakit dibanding dengan laki-laki.
Berdasarkan tabel 3, didapatkan data mayoritas pasien yang datang ke IGD dengan tingkat kegawatan PAC 2 sebanyak $304(94,7 \%)$ pasien. Hasil ini sesuai dengan penelitian yang dilakukan oleh Apriani \& Febriani (2017) mayoritas pasien prioritas 2 adalah $22(73,3 \%)$ pasien dari total 30 pasien.

Pasien dengan tingkat kegawatan PAC 2 adalah pasien dengan kriteria gawat tidak darurat dan darurat tidak gawat. Pasien yang gawat tidak darurat adalah pasien yang dalam keadaan gawat tetapi tidak memerlukan tindakan darurat (segera). Sedangkan pasien yang darurat tidak gawat adalah pasien yang terkena musibah yang tidak mengancam nyawa dan anggota badannya. (Mardalena, 2019)

Menurut analisis peneliti melihat dari sisi fungsionalitas, Instalasi Gawat Darurat yang digunakan untuk pelayanan pasien gawat darurat (triage merah dan kuning), dan pasien dengan kriteria triage hijau akan dilakukan pelayanan di unit poli rawat jalan. Dalam pengamatan peneliti, pasien yang datang ke IGD RS X adalah pasien dengan keluhan penyakit kronik seperti dengan kasus kardiovaskuler, internist, pulmonal, dan urologi. Banyak pasien dengan kondisi kronik yang lebih memilih untuk melakukan perawatan di RS X dikarenakan RS dikenal memiliki harga perawatan yang terjangkau dan dikenal sebagai RS yang membantu pasien

Berdasarkan tabel 4 didapatkan data mayoritas response time perawat dalam tindakan mandiri adalah sesuai dengan kriteria kegawatannya, sedangkan response time perawat dalam tindakan kolaboratif yang sesuai dengan kriteria kegawatannya sebanyak $319(99,4 \%)$ pasien. Response time 
yang sesuai adalah waktu penanganan disesuaikan dengan kriteria tingkat kegawatan pasien. Response time pasien untuk PAC 1 adalah $<5$ menit, dan response time untuk PAC 2 adalah $<45$ Menit. (Rumah Sakit Cinta Kasih Tzu Chi, 2019)

Hasil ini sesuai dengan penelitian yang dilakukan oleh Sinurat (2019) yang membuktikan dari 87 pasien bahwa response time perawat mayoritas sesuai pada 72 $(82,8 \%)$ pasien. Hasil ini juga sesuai dengan penelitian yang dilakukan oleh Maria Agustina, dkk. (2019) bahwa dari 93 responden, 90 diantaranya mendapatkan response time yang baik (rata-rata 27 detik) yang berarti sesuai.

Response time adalah kecepatan melayani/ melakukan tindakan secara cepat kepada pasien gawat darurat (Mardalena, 2019). Dalam penelitian ini peneliti membagi response time menjadi 2 yakni response time perawat dalam tindakan mandiri dan response time perawat dalam tindakan kolaboratif. Response time perawat dalam tindakan mandiri adalah waktu yang diperlukan oleh perawat untuk melakukan tindakan mandiri seperti pengecekan tandatanda vital yang dimulai saat pasien datang hingga waktu penanganan. Dalam pengamatan peneliti, pasien yang datang ke IGD langsung disambut oleh perawatdengan melakukan tindakan pengecekan tanda-tanda vital. Apabila ditemukan tanda- tanda vital yang memerlukan observasi maka pasien akan direkomendasikan untuk melakukan pendaftaran dan ditempatkan di bed yang sesuai dengan kondisi kegawatannya, dan apabila tidak ditemukan kegawatan maka pasien akan diarahkan ke poli yang sesuai dengan kondisi pasien. Dokter jaga IGD melakukan triage setelah pasien ditempatkan di bed yang kemudian diteruskan dengan tindakan kolaboratif perawat.

Response time perawat dalam tindakan kolaboratif dihitung sejak pasien datang hingga mendapatkan tindakan kolaboratif seperti terapi oksigen, pemberian terapi/ tindakan invasif, dilakukannya tindakan ekg, pemeriksaan rontgent, pemeriksaan laboratorium dan lain-lain. Dalam pengamatan, waktu pelaksanaan tindakan kolaboratif seringkali memanjang karena pasien yang datang tidak membawa identitas, tidak ada yang mau bertanggung jawab atas administrasi rumah sakit, diskusi yang terlalu lama untuk tindakan yangmemerlukan biaya lebih.

Dalam pengamatan peneliti rata-rata response time perawat dalam tindakan mandiri adalah 2 menit, dan 8 menit untuk tindakan kolaboratif. waktu terlama dalam melakukan tindakan mandiri adalah 15 menit. Hal ini terjadi karena kondisi IGD yang overcrowded. Hasil ini sesuai dengan penelitian Kundiman (2019) yang membuktikan adanya hubungan antara overcrowded dengan ketepatan triage. Waktu terlama dalam dilakukannya tindakan kolaboratif terjadi pada pasien dengan PAC 1 yakni 60 menit. Penyebab lamanya response time terhadap kondisi ini adalah tidak adanya keluarga pasien/ penanggungjawab pasien yang bersedia untuk menyutujui tindakan dan pemeriksaan yang diberikan. Pasien masuk pada kriteria usia lansia (75 tahun), tidak memiliki jaminan BPJS dan keluarga dekat. Yang membawa pasien menuju RS adalah tetangganya. Lamanya response time akan sangat berimbas dengan kecemasan keluarga pasien sebagaimana penelitian Maria Agustina (2019) bahwa ada hubungan 
antara response time dengan tingkat kecemasan keluarga pasien.

Standar Operasional Prosedur Rumah Sakit Cinta Kasih Tzu Chi mengenai kecepatan response time adalah PAC $1<5$ menit, PAC $2<45$ Menit, PAC $3<60$ Menit. (Rumah Sakit Cinta Kasih Tzu Chi, 2019). Dalam skala triage kanada, response time untuk kriteria darurat $<30$ menit, biasa $<60$ menit. Dalam Skala triage australia, response time untuk kriteria pasien yang "sedikit mengancam hidup", "berisiko mengancam hidup", "darurat" secara berturut-turut adalah 10 menit, 30 menit, dan

60 menit. PACS/ Patient Acuity Category Scale Membagi tingkat kegawatan menjadi 4 yakni PAC 1, PAC 2, PAC 3, dan PAC 4. (Fong, Glen, Jamil, Tam, \& Kowitlawakul, 2018).

Menurut analisis peneliti bahwa standar waktu penanganan diterapkan demikian karena kriteria masuk untuk pasien PAC 2 adalah jenis pasien yang gawat tidak darurat, dan darurat tidak gawat atau dengan katalain gabungan dari prioritas II (PAC 2) dan prioritas III (PAC 3) yang ada pada sistem triage singapura (PACS).

Berdasarkan tabel 5 didapatkan data mayoritas tingkat keberhasilan dalam penanganan pasien emergency di IGD adalah berhasil sebanyak 319(99,4\%) pasien. Hasil ini sesuai dengan penelitian yang dilakukan oleh Manurung (2018) bahwa dari 17 responden, 14 diantaranya berhasil dilakukan penanganan pada pasien cedera kepala.

Kriteria berhasil dan tidak berhasil dalam penelitian ini merujuk pada going to pasien. Pasien dikatakan berhasil dalam penelitian ini ditandai dengan pasien tidak meninggal dalam waktu $<8$ Jam di IGD, pasien dipulangkan, pasien rujuk ke Rumah sakit lain, pasien pindah unit keperawatan lain. Pasien dikatakan tidak berhasil dalam penanganan ditandai dengan meninggal $<8$ jam sejak pasien datang ke IGD.

Keputusan Menteri Kesehatan nomor 129/Menkes/SK/II/2008 tentang Standar Pelayanan Minimal Rumah Sakit menyebutkan jumlah pasien meninggal $<8$ jam sejak pasien datang tidak boleh menyentuh angka $<2 / 1000$ dalam satu bulan, yang berarti tingkat keberhasilan instalasi gawat darurat dalam menangani pasien emergency diperhitungkan dari tingkat jumlah angka kematian.

Dalam pengamatan peneliti, pasien yang berhasil dalam penanganan lebih banyak dipulangkan dan masuk unit rawat inap. Sebagian lainnya dirujuk dikarenakan kamar full, membutuhkan unit perawatan yangtidak dimiliki di RS X seperti membutuhkan pemeriksaan ct scan, membutuhkan perawatan spesialis kardiovaskular, perawatan hemodialisa, perawatan spesialis urologi, dan perawatan spesialis paru. Pasien yang tidak berhasil dalam penanganan iniada dua yakni pertama pasien berusia $<1$ Tahun datang dengan kondisi post kejang, dehidrasi berat dan datang sudah dengan penurunan kesadaran. Pasien kedua yakni bayi dengan dehidrasi berat dan gangguan jalan napas.

Faktor-faktor yang mempengaruhi tingkat keberhasilan penanganan pasien adalah beberapa kondisi seperti : kecepatan pasien ditemukan, kecepatan respon tenaga kesehatan, kemampuan dan kualitas tenaga kesehatan serta kecepatan minta tolong (Sartono, Masudik, \& Suhaeni, 2016). Pada poin pertama gagal ditepati yang mana kondisi pasien sudah terlambat untuk

DOI : https://doi.org/10.51544/imn.v4i1.1265

C 2021 Jurnal Mutiara Ners. This is an open accessarticleunder the CC BY-SA license Website : http://e-journal.sari-mutiara.ac.id/index.php/NERS/index 
mendapatkan penanganan. Pada poin kedua berhasil ditepati yakni response time tenaga kesehatan < 5 menit. (Penelitian oleh Putri \& Fitria (2018) menyatakan semakin cepat response time perawat semakin tinggi life saving). Kualitas tenaga kesehatan yang ada juga sudah tersertifikasi untuk Basic life support. Penelitian oleh Hartati \& halimuddin (2018) membuktikan adanya hubungan antara tingkat pengetahuandengan response time perawat.

Dengan uraian yang ada, peneliti berkesimpulan bahwa tingkat keberhasilan penanganan pasien di IGD tergolong berhasil dan mencapai standar pelayanan minimal yang ditetapkan oleh kementerian.

Berdasarkan tabel 5.6 didapatkan data mayoritas response time yang sesuai memiliki tingkat keberhasilan sebanyak 317 pasien. Hasil uji kendall's tau b didapatkan $p$ value $=0,314>0,05$ yang artinya tidak ada hubungan yang bermakna antara response time perawat dengan tingkat keberhasilan penanganan pasien emergency. Response time yang terbaik sekalipun apabila pasien terlambat ditemukan akan menjadi kurang maksimal dalam menyelamatkan pasien. Faktor internal pasien juga mempengaruhi tingkat keberhasilan penanganan pasien. Tiga faktorinternal yang mana adalah usia, jenis kelamin, serta tingkat kegawatan juga turut andil dalam tingkat keberhasilan penanganan pasien emergency. Dalam pengamatan peneliti, Response time yang dilakukan sudah cepat, akan tetapi adabeberapa faktor yang mempengaruhi tingkat keberhasilan penanganan pasien tersebut. Pasien yang tidak berhasil dalam penanganan adalah pasien dengan kategori usia bayi $<1$ Tahun datang dengan kondisi post kejang dan dehidrasi berat. Kondisi penanganan pre-hospital yang terlambat mempengaruhi tindakan selanjutnya dalam penanganan. Banyak faktor yang mempengaruhi tingkat keberhasilan pasien, seperti yang dikemukakan oleh Sartono dkk. (2016) bahwa tingkat keberhasilan penanganan pasien dipengaruhi oleh kecepatan pasien ditemukan, kecepatan respon tenaga kesehatan, kemampuan dan kualitas tenaga kesehatan dan kecepatan minta tolong. Tingkat kegawatan dengan PAC 1 berisiko tidak berhasil dalam penanganan yakni selain tingkat kegawatan PAC 1 (mengancam nyawa), pasien dengan usia rentan lebih berisiko untuk tidak berhasil.

\section{SIMPULAN}

Berdasarkan hasil penelitian mengenai hubungan antara response time perawat dengan tingkat keberhasilan penanganan pasien emergency di IGD RS X, maka dapat diambil kesimpulan mayoritas usia pasien yang datang ke IGD adalah kategori usia dewasa (18-64 Th) 57,9 \%, jenis kelamin perempuan $54,5 \%$, tingkat kegawatan pasien prioritas II 94,7\%, response time perawat dalam penanganan pasien emergency sesuai $99,4 \%$, tingkat keberhasilan penanganan pasien emergency berhasil 99,4\%.

Pada penelitian ini keberhasilan penanganan pasien tidak hanya dipengaruhi oleh reponse time saja namun juga oleh beberapa faktor seperti kompleksitas penyakit pasien, penanganan pasien prehospital. Saran untuk peneliti selanjutnya dapat meneliti kompleksitas diagnosis medis pasien beserta response time-nya dan dihubungkan dengan tingkat keberhasilan penanganan pasien. 


\section{REFERENSI}

Apriani, \& Febriani, S. (2017). Hubungan Kegawatdaruratan dengan Waktu Tanggap pada Pasien Jantung Koroner. Jurnal Kesehatan, 471-477.

Fadhilah, N., Harahap, W. A., \& Lestari, Y. (2015). Faktor-faktor yang Berhubungan dengan Waktu Tanggap pada Pelayanan Kasus Kecelakaan Lalu Lintas di Instalasi Gawat Darurat Rumah Sakit Umum Pusat Dr. M. Djamil Padang Tahun 2013. Jurnal Kesehatan Andalas, 4(1).

Fong, R. Y., Glen, W. G., Jamil, A. M.,Tam, W. S., \& Kowitlawakul, Y. (2018). Comparison of the Emergency Severity Index versus the Patient Acuity Category Scale in Emergency Setting. International Emergency Nursing.

Furwanti, E. (2014). Gambaran Tingkat Kecemasan Pasien di Instalasi Gawat Darurat RSUD Panembahan Senopati Bantul. Jurnal Universitas Muhamadiyah.

Hartati, S., \& Halimuddin. (2018). Response Time Perawat di Ruang Instalasi Gawat darurat.

Keputusan Menteri Kesehatan. (2008). Standar Pelayanan Minimal Rumah Sakit. Jakarta.

Keputusan Menteri Kesehatan. (2009). Standar Instalasi Gawat Darurat (IGD) Rumah Sakit. Jakarta.

Kundiman, V., Kumaat, L., \& Kiling, M. (2019). Hubungan Kondisi Overcrowded dengan ketepatan pelaksanaan triase di instalasi gawat darurat RSU GMIM Pancaran Kasih Manado. e-Journal Keperawatan Volume 7 No. 1.

Kurniati, A., Trisyani, Y., \& Theresia, S. I. (2018). Keperawatan Gawat Darurat dan Bencana Sheehy. Jakarta: Elsevier.
Mardalena, I. (2019). Asuhan Keperawatan Gawat Darurat. Yogyakarta: PUSTAKA BARU PRESS.

Pusponegoro, A. D., \& Sujudi, A. (2016). Kegawatdaruratan dan Bencana, solusi dan petunjuk teknis penanggulangan medik \&Kesehatan. Jakarta: PT. Rayyana Komunikasindo.

Putri, D., \& Fitria, C. N. (2018). Ketepatan dan Kecepatan terhadap life saving pasien trauma kepala. Jurnal The 7th University Research Colloqium 2018 STIKES PKU Muhammadiyah Surakarta.

Rumah Sakit Cinta Kasih Tzu Chi. (2019). Standar Pedoman Pelayanan Instalasi Gawat Darurat. Jakarta: Rumah Sakit Cinta Kasih Tzu Chi.

Sartono, H., Masudik, \& Suhaeni, A. E. (2016). Basic Trauma Cardiac Life Support. Bekasi: Gadar Medik Indonesia.

Sinurat, S., Perangin-angin, I. H., \& Sepuh, J. C. (2019). Hubungan Response timer perawat dengan tingkat kepuasan pasien BPJS di Instalasi Gawat Darurat. Jurnal Penelitian Keperawatan, 1-9.

Suhartati, \& et al. (2011). Standar Pelayanan Keperawatan Gawat Darurat di Rumah Sakit. Jakarta: Kementrian Kesehatan RI.

DOI : https://doi.org/10.51544/jmn.v4i1.1265

(C) 2021 Jurnal Mutiara Ners. This is an open accessarticleunder the CC BY-SA license Website : http://e-journal.sari-mutiara.ac.id/index.php/NERS/index 